\title{
5. A Arte de Redigir um Trabalho Científico ${ }^{1}$
}

\author{
The art of writing a scientific paper
}

Fabio Xerfan Nahas ${ }^{2}$, Lydia Masako Ferreira ${ }^{3}$

1. Programa de Pós-Graduação em Cirurgia Plástica da Universidade Federal de São Paulo - Escola Paulista de Medicina (UNIFESP-EPM). Disciplina de Cirurgia Plástica da UNIFESP-EPM.

2. Professor Adjunto Visitante da Disciplina de Cirurgia Plástica da UNIFESP-EPM. Professor Orientador do Programa de Pós-Graduação em Cirurgia Plástica UNIFESP-EPM.

3. Professora Titular da Disciplina de Cirurgia Plástica da UNIFESP-EPM. Coordenadora do Programa de Pós-Graduação em Cirurgia Plástica da UNIFESP-EPM.

\section{RESUMO}

A redação científica e suas particularidades são descritas neste artigo. A dificuldade do autor-médico ao escrever, o uso inadequado do jargão médico e as regras básicas de escrita são analisados. O autor é orientado, desde o início da fase de redação do trabalho, a como colocar suas idéias progressivamente no papel de modo a organiza-las em um rascunho inicial e, subseqüentemente, ir melhorando este manuscrito. As idéias de simplificação de escrita, ordem direta e objetividade numérica que são a base da redação científica estão relatadas e discutidas.

Descritores: Redação, Artigo de Revista, Editoração

\begin{abstract}
The special characteristics of the scientific writing are described in this paper. The difficulty of writing of the medical author, the inadequate use of the medical jargon and the writing basic rules are analyzed. The author is oriented since the initial stage of the writing and how to progressively write his ideas, organizing them on a draft and improving the manuscript. Good writing such as the use of simple terms, direct order and objectivity which are reported and discussed. Key words: Writing, Journal Article, Publishing.
\end{abstract}

O objetivo principal do pesquisador é a realização do estudo. A fase de redação do artigo é, por vezes, difícil para muitos autores. Esta fase é de fundamental importância, já que a divulgação do estudo entre seus pares está diretamente ligada à redação da pesquisa. Entretanto o processo de colocar o estudo em termos concretos e organiza-lo em um padrão lógico pode ser extremamente útil ao pesquisador. Nesta fase o autor tem a oportunidade de relacionar seu trabalho, de forma mais sistemática, aos estudos disponíveis na literatura, o que irá chamar atenção para dados que podem ter passados desapercebidos ${ }^{1}$.

O rascunho inicial do texto deve ser escrito de uma só vez, já de acordo com os itens do trabalho científico. Este material bruto passará a ser trabalhado e será melhorado ao longo de várias revisões. Durante estas revisões, deve-se procurar eventuais repetições e verificar se, por outro lado, faltou incluir algum fato relevante no texto.

Todo artigo, durante sua redação, passa por algumas fases de amadurecimento. É difícil especificar estas fases, pois acontecem simultaneamente. Seqüencialmente devese: 1) Colocar as idéias no papel; 2) Ordenar as idéias (reagrupamento dos parágrafos, coordenando os assuntos em seqüência lógica); 3) Dar o acabamento ao texto (correção gramatical, da concordância e de estilo).
É interessante imprimir o artigo para efetuar as correções em cada fase para facilitar a visualização dos pontos a serem corrigidos ${ }^{2}$.

A clareza e objetividade devem estar sempre na mente de quem escreve, pois este é um dos pontos que serão julgados pelos revisores. Um texto longo não significa que será mais bem compreendido pelo leitor. Nestes casos, dados e idéias expostos em excesso podem tornar a leitura mais árdua. Além disso, os periódicos procuram reduzir os textos para obter redução de custo. Desta forma, o estilo deve ser conciso, procurando-se eliminar frases introdutórias óbvias como: “Os autores apresentam, neste estudo, os resultados obtidos....”.

Outro fator que prejudica a qualidade da redação do trabalho científico é a descrição de detalhes supérfluos de certas etapas do método. Um exemplo prático deste tipo de distorção é explicar que, na descrição da realização de um retalho cutâneo, incisa-se antes a pele e, a seguir, o tecido subcutâneo. Para o leitor de uma revista especializada a descrição deste pormenor seria uma perda de tempo, já que o exposto é óbvio. Se o leitor fosse leigo, seria cabível uma explicação deste tipo ${ }^{3}$.

Ao redigir artigos científicos, alguns pontos devem ser observados: 1) Utilizar sentenças em ordem direta; 2) Evitar sentenças longas, deve-se dividi-las com ponto final; 3) Sempre usar o termo mais simples possível; 4) 
Sempre utilizar termos concretos e específicos ${ }^{4}$.

Um vício muito comum de médicos que se iniciam na arte da redação é o uso do pronome pessoal "nós" nos textos científicos. Este é um hábito transferido das apresentações orais, nas quais a primeira pessoa do plural pode ser utilizada. Ao escrever um artigo, o autor deve tomar o cuidado de ser impessoal, usando termos como “O estudo provou...” ou "Os resultados indicaram...”.

O jargão médico, palavras habitualmente utilizadas em discussões clínicas, mas que correspondem a um vício de linguagem, devem ser evitados. Um exemplo é a palavra patologia quando utilizada como sinônimo de doença; este termo deve ser substituído por alteração patológica ou mesmo por doença - um termo mais simples e claro. Abdome superior deve ser substituído por região superior do abdome ${ }^{5}$. Estes são apenas algumas situações corriqueiras do uso de jargões, entretanto o uso da “Nomina Anatomica” deve ser uma regra quando estruturas e regiões anatômicas forem descritas.

O uso de abreviaturas no texto deve ser utilizado com parcimônia. Em artigos científicos, a abreviatura deve ser introduzida e claramente explicada na primeira vez que aparecer no texto. Abreviaturas não devem ser utilizadas no título ou no resumo (exceto em casos consagrados) para evitar confusão. A abreviação de unidades de pesos e medidas pode ser utilizada abreviada quando juntas a numerais (por exemplo: 10 g, 25 ml, etc...). Quando enunciadas isoladamente, devem ser escritos por extenso (por exemplo: grama, mililitro, etc...).

Os números quando escritos no texto devem, em geral, ser colocados na forma de algarismos. Entretanto, existem alguns periódicos que orientam os autores a escrever por extenso os números de um a dez. No início de uma sentença, deve-se escrevê-lo por extenso, por exemplo: "Vinte dos animais estudados...”. Quando os números estão separados por vírgula, em continuidade, deve-se escrever um deles por extenso e representar o outro com algarismo arábico, por exemplo: "Dos três, 4 apresentaram...”. Quando há unidade ou símbolo de porcentagem associado ao número, deve estar sempre representado por algarismos arábicos, “ 4 ml, 5\%, etc...
Uma regra importante que nem sempre é respeitada por pesquisadores é o fato de se atribuir a um autor uma idéia que foi apresentada como de outro autor. Isto é um erro de revisão, devendo, portanto, ser evitado. Pode dar a impressão de que foi utilizada uma fonte de “segunda mão”, de forma inconsciente ou não.

Redação em língua estrangeira é sempre um desafio maior. Tradutores podem não ter o domínio de termos técnicos. Mesmo que o tenham, dificilmente são conhecedores de termos da especialidade, desta forma é importante que o autor tenha algum conhecimento da língua na qual o artigo será escrito. Se não for o caso, será útil a revisão por algum colega da especialidade que domine o idioma no qual o artigo será escrito. Por outro lado, o autor que tem um domínio melhor da língua, embora não seja sua língua-mãe, poderá desenvolver o texto de forma mais simples e objetiva. Isto ocorre porque o número de palavras conhecidas por um estrangeiro é menor e seu vocabulário é mais básico do que o de um indivíduo que escreva em sua língua-mãe. Deste modo, pode-se tirar vantagem ao se escrever um trabalho em outro idioma no qual o pesquisador tenha um conhecimento básico do idioma.

\section{Referências}

1. Meadows AJ. A Comunicação científica. 1st. ed. Brasília: Editora Briquet de Lemos; 1999.

2. Nahas FX, Ferreira LM, Sabino Neto M, Garcia EB. Elaboração de trabalho científico. Rev Bras Cir Plast. 2004 19(2):11-28.

3. Rey L. Como redigir trabalhos científicos. 1st. ed. São Paulo: Editora Edgard Blücher (Editora da Universidade de São Paulo); 1972.

4. Martins E. Manual de redação e estilo de O Estado de São Paulo. 3rd. ed. São Paulo: Editora O Estado de São Paulo; 1997.

5. Fishbein M. Medical writing. 3rd. ed. York: McGrawHill; 1957.

\section{Correspondência:}

Fabio Xerfan Nahas

Disciplina de Cirurgia Plástica / Departamento de Cirurgia

Universidade Federal de São Paulo (UNIFESP - EPM)

Rua Napoleão de Barros, 715 - $4^{\circ}$ andar

04024-900 São Paulo - SP Brasil

Tel: (5511) 5576-4118

nahas.dcir@epm.br

\section{Como citar este artigo:}

Nahas FX, Ferreira LM. A arte de redigir um trabalho científico. Acta Cir Bras [periódico na Internet] $2005 ; 20$ Suppl. 2:17-8. Disponível em URL: http://www.scielo.br/acb 